\title{
Trainees' Characteristics in Training Transfer: The Relationship among Self-Efficacy, Motivation to Learn, Motivation to Transfer and Training Transfer
}

\author{
Melody Ling-Yu Wen \\ Professor of Department of Finance, National Changhua University of Education, \\ Changhua, Taiwan \\ No.2, Shi-Da Road, Changhua 500, Taiwan \\ Danny Yung-Chuan Lin \\ Doctoral Student of Department of Finance, National Changhua University of Education, \\ Changhua, Taiwan \\ No.2, Shi-Da Road, Changhua 500, Taiwan \\ E-mail: danny.mailbox@msa.hinet.net
}

Doi:10.5296/ijhrs.v4i1.5128

URL: http://dx.doi.org/10.5296/ijhrs.v4i1.5128

\begin{abstract}
Training transfer is important for researchers and practitioners as organization invests much budget in training but reaps only lower estimation of transfer in practical domains. Researches revealed training design and work environment characteristics are important variables which influence training transfer. This study intended to examine individual level of trainee characteristics exclusively by structural equation modeling (SEM) from broad industries in Taiwan by 500 questionnaires sent to participants with 316 usable returns in $63.2 \%$ return rate. The result revealed the fully prediction role of motivation on self-efficacy to training transfer. Without other study setting, self-efficacy, motivation to learn, motivation to transfer, and training transfer are sorted sequentially.
\end{abstract}

Keywords: Self-efficacy, Motivation to learn, Motivation to transfer, Training transfer 


\section{Introduction}

Training is necessary short-term intervention implement, which improves individuals shortly by instructing them with important and sufficient knowledge, skills and attitudes that individuals need to meet environmental change (Rothwell \& Sredl, 2000), and long-term intervention implement with systematic process, which develops individuals' knowledge and competence for their careers (Blancher \& Thacker, 1999). As an important implement in organizational contexts, either short-term or long-term intervention is proposed to enhance individuals' productivities and instruct the organizational goals to them (Arthur, Bennett, Edens, \& Bell, 2003). In another word, training should be positively transferred into the workplace (Berry \& Morris, 2005) to meet the ultimate goal of training which is purposed to obtain benefits from training that employees apply what they have learned to the workplace (Salas \& Cannon-Bowers, 2001).

Training transfer is described as the grade of trainees who apply the knowledge, skills, behaviors and attitudes they obtained from training program into their work context which may improve their job performance (Velada \& Caetano, 2007). In term of research, Vroom's (1964) expectancy theory and "transfer of training model" were utilized mostly which included the most important sets of variables with training design, trainee characteristics, and work environment characteristics (Baldwin \& Ford, 1988). Besides, Motivation Theory is a foundational topic in psychological and organizational studies because it drives the actions and performs particular task successfully. In general, Motivation Theory contains intrinsic and extrinsic motivation constructs that can be used to predict achievement and achievement related behaviors. Nevertheless, intrinsic motivation originates from within the individual and results in enjoyment of the process of the particular task (Deci \& Ryan, 2000) which may enhanced by another important construct self-efficacy, of motivation theory which described the belief that one is capable of successfully performing a particular task (Bandura, 1986).

Based on the Motivation Theory which contains self-efficacy, intrinsic and extrinsic motivation constructs. This study particular focused exclusively on the trainee characteristics including self-efficacy (e.g., Ford, Quinones, Sego, \& Sorra, 1992), motivation to learn (e.g., Kontoghiorghes, 2002 ; Tracey, Hinkin, Tannenbaum, \& Mathieu, 2001), and motivation to transfer (e.g., Kontoghiorghes, 2002 ; Ruona, Leimbach, Holton, \& Bates, 2002) that have been found by researchers to facilitate the training transfer process with the training design and work environment characteristics interventions. Therefore, to examine the relationship among the trainee characteristics variables exclusively without other setting become the main motivation of this study. Moreover, this study also intended to hypothesize and examine the role of motivation (motivation to learn / motivation to transfer) between self-efficacy and training transfer according to Holton's (1996) disclosure that training motivation is a key way to connect training with individual performance change.

Additionally, in terms of research, the effectiveness paths between training motivation and self-efficacy were reveled in opposed direction in different studies with diverse interventions (Colquitt, LePine \& Noe, 2000 ; Noe \& Schmitt, 1986 ; Quiñones, 1995 ; Tannenbaum \& Yukl, 1992). It is one more motivation of this study to present its necessities to fill the 
theoretical gaps by examining its relationship with trainee characteristics level (self-efficacy, motivation to learn and motivation to transfer) exclusively.

Based on the concern of the relationship among trainee characteristics level and the effectiveness paths between self-efficacy and motivation, this study purposes to identify :

(1). Both self-efficacy and training motivation should predict on training transfer.

(2). Motivation to transfer would be the mediator of both self-efficacy and motivation to learn on training transfer.

(3). The path way among self-efficacy, training motivation, and training transfer in trainee characteristics context.

Subsequently, this article will be constructed with literature review to assume its hypotheses, study method, measures, analytical procedure, results and discussion. Finally, some theoretical and managerial implications and study limitations with future research suggestion are provided.

\section{Literature Review}

\subsection{Training transfer}

Training transfer is defined as "the application continued by learners to performance of jobs, individuals, community responsibilities of knowledge in learning activities" (Broad, 1997, p. 2), which focused on how individuals adapt their new learning in change environment over time. In addition to enhance individuals' skills and knowledge, an efficient training is also comprised the trainees' adaptive abilities of knowledge, skills and abilities gained in training programs into the job practices (e.g., Baldwin \& Ford, 1988 ; Ford \& Weissbein, 1997 ; Tannenbaum \& Yukl, 1992). In other words, it has become a key criterion for evaluating the effectiveness of training programs (Baldwin \& Ford, 1988) that training transfer attributes to the level of trainees who adapt knowledge, skills, behaviors, and attitudes into their workplace after training to improve their job performance by the generalization of training to work context continuously (Velada \& Caetano, 2007).

\subsection{Self-efficacy}

Self-efficacy is conceptualized by social learning theory (Bandura, 1986), as "peoples' judgments of their capabilities to organize and execute courses of action required to attain designated types of performance. It is concerned not with the skills one has but with the judgments of what one can do with whatever skills one possesses." (Bandura, 1986, p. 391). It is the consists of individuals' belief that they have the abilities to perform a task successfully with a specific level of performance (Wood \& Bandura, 1989). Research indicates that individuals with higher self-efficacy position themselves with more challenging goals, in contrast, individuals with lower self-efficacy (Bandura, 1986) who are less likely to be exposed new position (Hill, Smith, \& Mann, 1987), that limit individuals' abilities to cope benefit from training involvement.

Several meta-analyses substantiated the relationship between self-efficacy and outcomes 
which were connected to either performance (Stajkovic \& Luthans, 1998) or training (Colquitt et al., 2000). Haccoun and Saks (1998) also disclosed that self-efficacy is one of the primary determinants of proximal training outcomes. Another finding from training research indicated self-efficacy was the central role for enhancing training effectiveness and the transfer development (Mathieu, Martineau, \& Tannenbaum, 1993). Hence, present study hypothesizes as :

H1: Self-efficacy positively predicts training transfer.

\section{2-3 Motivation to learn:}

In a training context, motivation influences the willingness of trainees to attend the training program (Maurer \& Tarulli, 1994 ; Noe \& Wilk, 1993), to exert energy toward the program, and to utilize his/her learning on the job (Baldwin \& Ford, 1988). Trainees may not reap full benefits of training programs without consideration of motivation to learn (Tai, 2006) that indicates motivation plays a critical role in performing training effectiveness even if trainees have the capabilities to master the content of training programs but may be failed in gaining training benefits due to their lower motivation to learn (Colquitt et al., 2000).

In empirical studies, Cheng and Ho (2001) surveyed studies conducted in pass years and terminated that motivation to learn influences trainees' training performance and transfer outcomes. Previous studies summarized by meta-analysis indicated that motivation to learn is a robust predictor of training outcomes and influenced by individual characteristics (e.g., self-efficacy) (Colquitt et al., 2000). Therefore, hypotheses were revealed as below.

$\mathrm{H} 2$ : Motivation to learn positively predicts training transfer.

H3: Self-efficacy positively predicts motivation to learn.

\section{2-4 Motivation to transfer}

Based on the theories of expectancy, equity, and goal setting which affect the desirable degree of training transfer (Yamnill \& McClean, 2001), motivation to transfer refers to the desires of individual who utilizes and connects the knowledge and skills obtained from training programs to their workplace (Noe \& Schmitt, 1986) which involved individual's inspiration to reassign knowledge and skills from training to a job-specific context (Seyler, Holton, Bates, Burnett, \& Carvalho, 1998).

Vroom originally argued expectancy theory as "a momentary belief concerning the likelihood that a particular act will precede a particular outcome."(Vroom, 1964, p.17), while Moorhead and Griffin (1992) described expectancy theory presented by Porter and Lawler (1968) in a notion of the relationship between employee satisfaction and performance. If intangible intrinsic rewards such as a feeling of accomplishment, a sense of achievement are adequate, higher levels of performance may lead to satisfaction (Porter \& Lawler, 1968), that employees may be motivated to transfer their knowledge and skills obtained from training programs in gaining the opportunities for advancement (Kontoghiorghes, 2001). Equity theory is simply described that people desire to obtain fairly treatment (Adams, 1963) which was revealed its relationship with motivation to transfer by Noe (1986) that there is a greater 
chance to transfer the knowledge and skills by individual who obtains equity in pay (tangible extrinsic rewards) or other sought-after rewards which may relate to intangible intrinsic rewards. On the contrary, explicit goal-setting assignment programs obtain a higher level of adaption of knowledge and skills into job performance than other group which has no goals assignment (Wexley \& Nemeroff, 1975). According to the notion of Locke (1968), goals guide attention and action that trainees who were mandated to engage in a training program also found stronger transfer intention by Baldwin, Magjuka, and Loher (1991). In addition, they organize effort in proportion to perceive requirements of the goal or task (Locke, Shaw, Saari, \& Latham, 1981).

Motivation to transfer is the intention of participant to utilize knowledge and skills obtain in training program into job performance (Noe, 1986). Evidences from study by Axtell, Maitlis, and Yearta (1997) revealed motivation to transfer positive predicts training transfer. Moreover, Chiaburu \& Lindsay (2008) also found motivation to transfer primarily predicted training transfer with training instrumentality. Therefore, the following hypothesis would be examined to clarify the relationship between motivation to transfer and training transfer.

H4: Motivation to transfer positively predicts training transfer.

Furthermore, motivation to transfer had been revealed as an important outcome variable affected by participant's motivation to learn (Kontoghiorghes, 2002) and self-efficacy (Machin \& Fogarty, 1997). Besides, motivation to transfer had also been found its mediation role between motivation to learn and training transfer (Chiaburu \& Lindsay, 2008). Therefore, this study raised other hypotheses as below.

H5: Motivation to transfer mediates the relationship between self-efficacy to training transfer.

H6: Motivation to transfer mediates the relationship between motivation to learn to training transfer.

Figure 1 is developed by this study according to above literatures review and hypotheses.

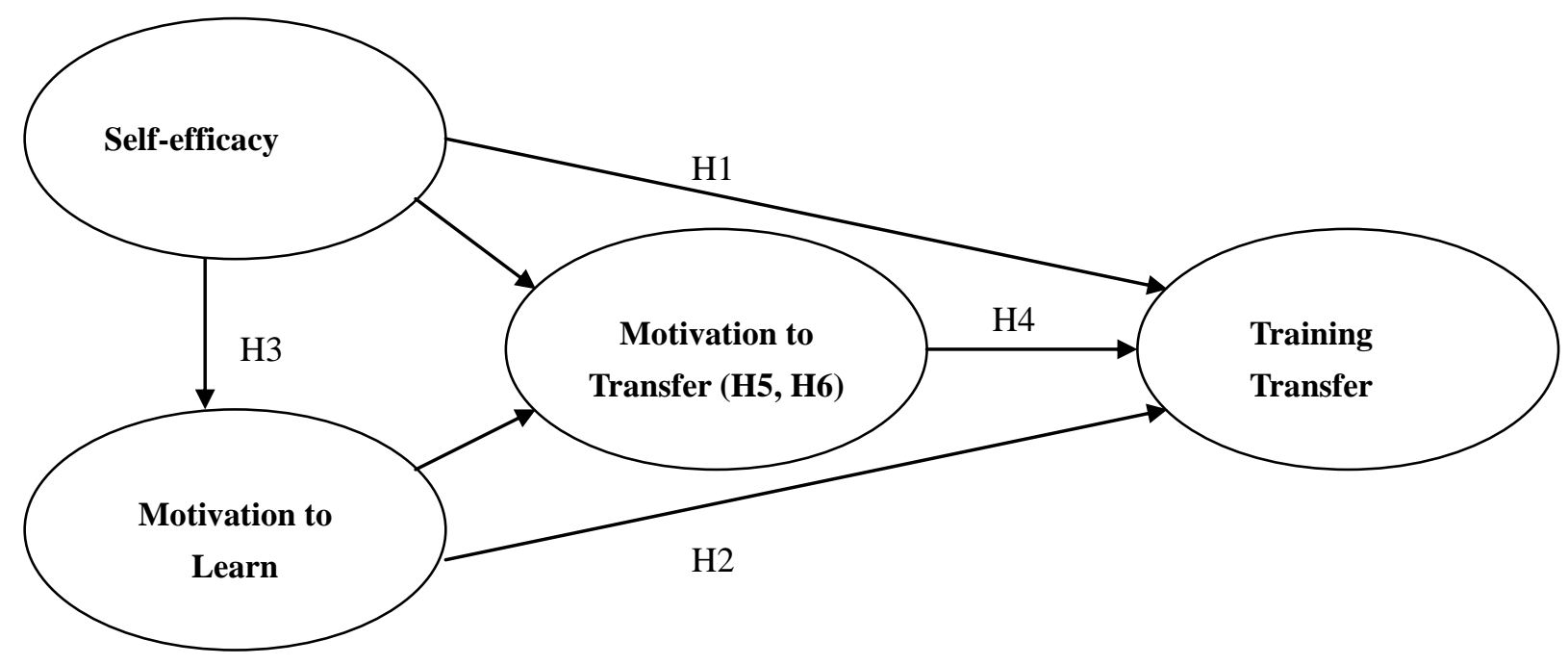

Figure 1. Study model 


\section{Method}

\subsection{Participants}

This study tends to measure and analyze training rated by individual level as the source of measurement and analysis due to training employees focus on individual level more than group as the nature of training goal is to facilitate the participants with knowledge and skills obtained from training programs (Rothwell \& Sredl, 2000). Organizations rely on their employees' intention to keep learning and utilize their training contents to carry out their goals (Sharon \& Holton, 2002). Therefore, this study intended to examine the prediction roles of training transfer with individuals' characteristics including self-efficacy, motivation to learn, and motivation to transfer. Convenient samples are contained full-time employees from broad industries in Taiwan. 500 questionnaires were sent out and 316 usable returns were collected with $63.2 \%$ response rate. $53.5 \%$ of the sample was male, and $43.0 \%$ was female. $71.5 \%$ of the participants were positioned as front-line workers/staffs, others were first-line managers $(18.4 \%)$, middle managers $(7.3 \%)$, and top managers $(2.5 \%)$. Participants who volunteered to participate this study were averaged 36.3 years old. Most of them were educated with graduate/college level in $79.1 \%$.

\subsection{Measures}

This survey questionnaire contained 18 items distributed into four variables as below. Participants indicated the extent to which they agree with each of the statements on a 5-point Likert scale (1 strongly disagree to 5 strongly agree).

\subsubsection{Training transfer}

Four items from Xiao (1996) which had also been utilized by Scaduto, Lindsay, and Chiaburu (2008) were selected to be slightly modified to rate the level of training transfer. The sample item is "I can accomplish the job tasks better by using new knowledge acquired from the training." By implementation of Confirmatory factor analysis, the scales reaped a good model fit indices $\left(\chi^{2} /\right.$ d.f. $=2.979, \mathrm{GFI}=.991, \mathrm{RMR}=.006, \mathrm{RMSEA}=.079, \mathrm{AGFI}=.956, \mathrm{CFI}=.992$, $\mathrm{SRMR}=.0184)$ with internal consistency reliability in Cronbach's alpha .845 .

\subsubsection{Self-efficacy}

Five items developed by Noe and Schmitt (1986) had been used to observe the data of self-efficacy with sample item as "When I take training courses in unfamiliar areas. I expect to be able to do well at them." Confirmatory factor analysis result shows the scales obtained a good model fit indices $\left(\chi^{2} /\right.$ d.f. $=2.124, \mathrm{GFI}=.986, \mathrm{RMR}=.007, \mathrm{RMSEA}=.060, \mathrm{AGFI}=.959$, $\mathrm{CFI}=.990, \mathrm{SRMR}=.0214)$ with internal consistency reliability in Cronbach's alpha .839 .

\subsubsection{Motivation to learn}

Four items from Noe and Schmitt (1986) were utilized to rate the level of trainees' motivation to learn with sample item that "I try to learn as much as I can from training programs," which obtained a good model fit indices of Confirmatory factor analysis result $\left(\chi^{2} /\right.$ d.f. $=1.429, \quad \mathrm{GFI}=.996, \mathrm{RMR}=.005, \mathrm{RMSEA}=.037, \mathrm{AGFI}=.978, \mathrm{CFI}=.998$, 
$\mathrm{SRMR}=.0145)$ and has its internal consistency reliability in Cronbach's alpha .810.

\subsubsection{Motivation to transfer}

Five items also from Noe and Schmitt (1986) were utilized to rate the level of trainees' motivation to tranfer with sample item that "I believe my job performance will likely improve if I use the knowledge and skills acquired in training programs," which has a good model fit indices of Confirmatory factor analysis result $\left(\chi^{2} /\right.$ d.f. $=.996, \mathrm{GFI}=.994, \mathrm{RMR}=.005$, $\mathrm{RMSEA}=0, \mathrm{AGFI}=.981, \mathrm{CFI}=1.0, \mathrm{SRMR}=.0158)$ and its internal consistency reliability in Cronbach's alpha .842 .

\subsection{Analyses}

Structural equation modeling (SEM) was utilized to explore the relationships among self-efficacy, motivation to learn, motivation to transfer, and training transfer which is a multivariate statistical tool provides researchers with an absolute methodology for examination and quantification of theories (Joreskog \& Sorbom, 1996). Besides, SEM measures error and tests both direct and indirect structural hypotheses and the analysis results are contrasted with established standards for estimated fit, which evaluates the strength of the finding compared to the proposed model as a confirmatory investigation by present study. Moreover, SPSS was also processed to show means, standard deviations and correlations for variables in this study.

\section{Results}

Table 1 provides the means, standard deviations and correlations for variables in this study which shows the correlation between variables. The result shows there is no collinear problem between independent variables (inter-correlation < .8) (Katz, 1999). To examine the model presented in Figure 1, this study applied AMOS to examine the model fit which brought out the path coefficients as Figure 2. The model fit indices were compiled into values included CMIN/DF in 1.753 which comforted to the acceptable range lower than 3 suggested by Bagozzi and Yi (1988). The Goodness of Fit Index (GFI) is in .928, the Comparative Fit Index (CFI) is in .965, and the Adjust Goodness of Fit Index is in .905 which comforted to the acceptable values higher than .9. The RMR, root mean square residual is in .014, which comforted to the acceptable values lower than .05, and the RMSEA, root mean square error of approximation is .049 which was suggested by Browne and Cudeck (1993) that the acceptable value is lower than .1. Finally, standardized root mean residual (SRMR) is .0411 which conformed to the acceptable value lower than .05. Based on above indications, the overall structural model of this study is acceptable as stated in Table 2. 
Table 1 Means, standard deviations, correlation matrix

\begin{tabular}{ccccccc}
\hline Variables & Mean & SD & 1 & 2 & 3 & 4 \\
\hline 1. SE & 3.95 & .452 & 1.00 & & & \\
2. MTL & 4.09 & .461 & $.674^{* *}$ & 1.00 & & \\
3. MTT & 3.87 & .453 & $.518^{* *}$ & $.660^{* *}$ & 1.00 & \\
4. TT & 3.89 & .480 & $.514^{* *}$ & $.643^{* *}$ & $.737^{* *}$ & 1.00 \\
\hline
\end{tabular}

Note: SE, Self-Efficacy; MTL, Motivation to learn; MTT, Motivation to transfer; TT, Training transfer. ${ }^{*} p<.05 * * p<.01$

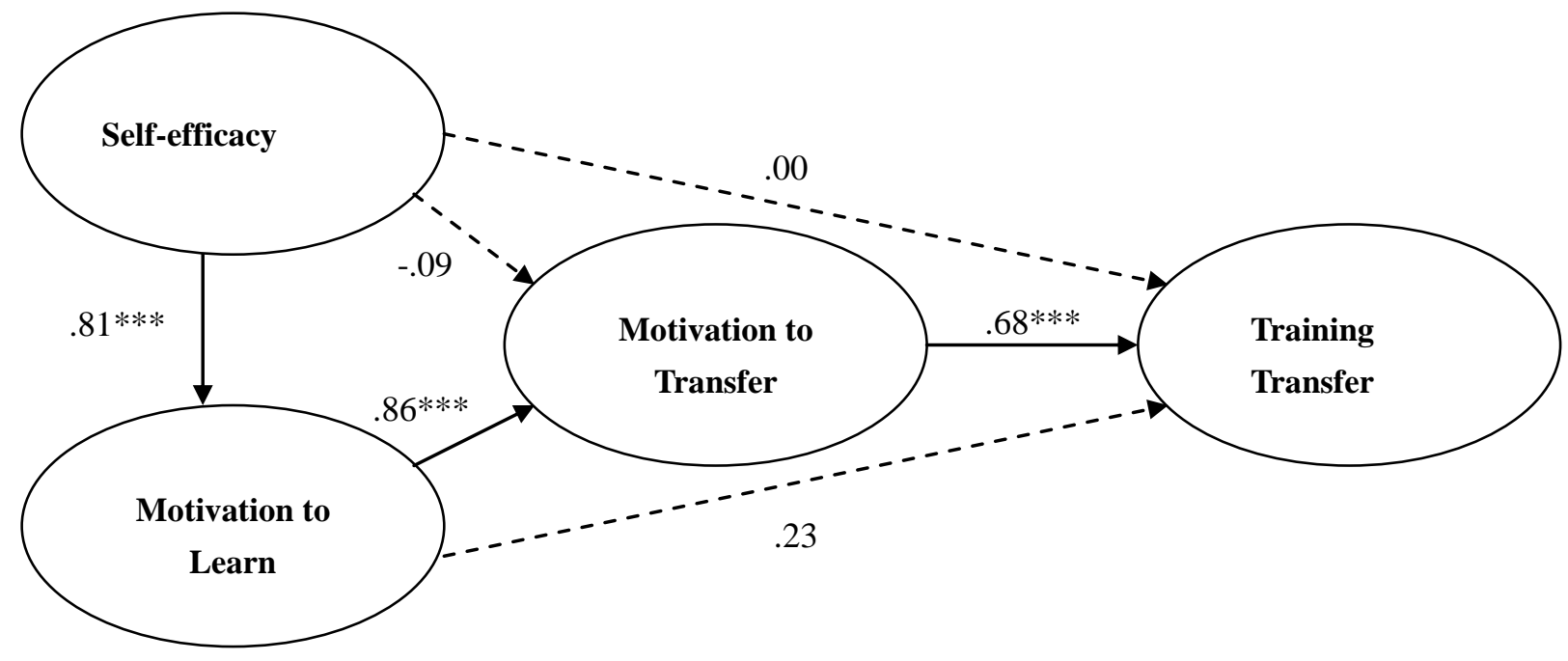

Figure 2. Tested model: path coefficients

$$
* * * p<.001
$$

Table 2 Goodness of fit statistics

\begin{tabular}{cccccccc}
\hline Model/Construct & $\begin{array}{c}\text { CMIN } \\
\text { /DF }\end{array}$ & GFI & RMR & RMSEA & AGFI & CFI & SRMR \\
\hline CFA & 1.753 & .928 & .014 & .049 & .905 & .965 & .0411 \\
Suggested Values & $<3$ & $>.9$ & $<.05$ & $<.1$ & $>.9$ & $>.9$ & $<.05$ \\
\hline
\end{tabular}

\subsection{Findings and Discussions}

The focus of the present study was on developing and testing a model, which investigated individual's characteristics including self-efficacy, motivation to learn, motivation to transfer, and the dependent variable of training transfer without other training design and work environment characteristics interventions. The testing demonstrated that hypotheses 3, 4, and 6 were supported and numerous of meaningful findings emerged from present empirical investigation.

Firstly, self-efficacy was found positively associated with motivation to learn with a coefficient in .81 (C.R./Critical ratio for regression weight in 10.206, $p<.001$ ) which 


\section{Ml Macrothink}

demonstrated that hypothesis 3 was fully supported. Except to extend and reinforce the finding by Chiaburua and Lindsay (2008) that self-efficacy is related primarily to motivation to learn, the result also revealed that higher level self-efficacy individual tend to have confident belief of one's capabilities of successfully performing a particular task which drives one's intrinsic motivation than enhance the motivation to learn. The meaningful finding complied with Motivation Theory that self-efficacy is an important construct of motivation theory which drives one's motivation primarily (Bandura, 1986).

Motivation to transfer was hypothesized its predictor role on training transfer which was also found its impact on training transfer with coefficient .68 (C.R./Critical ratio for regression weight. in 6.464, $p<.001$ ). Hypothesis 4 was fully supported and extended the finding by Chiaburu and Lindsay (2008) that training transfer is predicted primarily by motivation to transfer with training instrumentality. The result also confirmed the predictor role of motivation to transfer to training transfer (Chiaburu \& Tekleab, 2005 ; Tracey et al., 2001).

Regarding the mediator role of motivation to transfer, present study hypothesized motivation to transfer mediates the relationship between self-efficacy to training transfer as hypothesis 5, and motivation to transfer mediates the relationship between motivation to learn to training transfer as hypothesis 6 . Since hypothesis 1 and 2 were not supported by the assessment implementation in this study, the partial mediation effectiveness of motivation to transfer was not found and hypothesis 5 was not supported, but hypothesis 6 was supported with a coefficient in .86 (C.R./Critical ratio for regression weight. in 6.091, $p<.001$ ) as full mediation effectiveness as motivation to transfer fully mediated the relationship on motivation to learn to training transfer. The result become a reinforced evidence of the finding by Chiaburu and Lindsay (2008) and confirmed the positive relationship between motivation to learn and motivation to transfer found by previous studies (e.g., Naquin \& Holton, 2002 ; Ruona et al., 2002) which reinforced the general knowledge of the motivation in line with prior theoretical (Cannon-Bowers, Salas, Tannenbaum, \& Mathieu, 1995) and empirical works (Tannenbaum, Mathieu, Salas, \& Cannon-Bowers, 1991). According to the Motivation Theory, intrinsic motivation attributes to one's desire to spend effort based on interests and enjoyment of the task itself (Gagné \& Deci, 2005). In contrast, extrinsic motivation attributes to one's desire to spend effort to gain something outside of the task itself, such as rewards or recognition (Amabile, 1993). As hypothesis 3 was supported which revealed self-efficacy drives one's intrinsic motivation to enhance motivation to learn based on one's confidences, interests and enjoyment of the task itself, in contrast, motivation to transfer become extrinsic motivation based on the theories of expectancy, equity, and goal setting that someone expects the outcomes external to the task itself which affect the desirable degree of training transfer (Yamnill \& McClean, 2001). The finding of the mediation role of motivation to transfer between motivation to learn and training transfer disclosed that intrinsic motivation occurs before extrinsic motivation in the study.

Finally, the unsupported hypotheses in this study may be explained as the results of different setting in studies. Although, self-efficacy (e.g., Ford et al., 1992), motivation to learn (e.g., Kontoghiorghes, 2002 ; Tracey et al., 2001) and motivation to transfer (e.g., Kontoghiorghes, 2002 ; Ruona et al. , 2002) might be found their effectiveness to training transfer process, but 
most of them might be implemented with expectancy theory and "transfer of training model" as frame work with training design and work environment characteristics in studies (Baldwin $\&$ Ford, 1988). Without any other setting, the purely trainee characteristics implementation in this study revealed the sequent relationship of self-efficacy, motivation to learn, motivation to transfer, and training transfer as Figure 3. Training participants' training self-efficacy can be powerful motivational force and impact on the distal outcomes as training transfer (Chiaburua \& Lindsay, 2008).

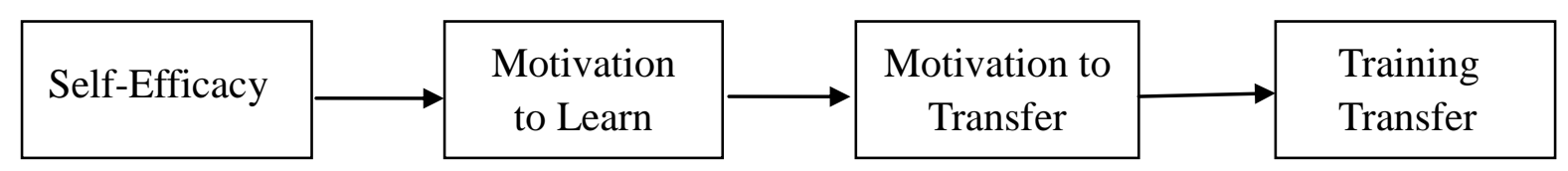

Figure 3. The sequence of trainees characteristics in training transfer.

\subsection{Theoretical implications}

This study had not found self-efficacy significant association to training transfer, although it was found its relationship to either performance (Stajkovic \& Luthans, 1998) or training (Colquitt et al., 2000) as one of the primary determinants of proximal training outcomes (Haccoun \& Saks, 1998) in other training design and work environment characteristics interventions. The founding of this study revealed the important messages of role of motivation (motivation to learn / motivation to transfer) which fully mediated the relationship between self-efficacy and training transfer. The founding theoretically consisted with the purpose of this study to identify the path way between self-efficacy, motivation, and training transfer which revealed the importance of motivation in purely trainee characteristics setting. Without motivation, training transfer will not be occurred appropriately even trainee has sufficient confident in any training instrumentality. Besides, whether motivation was typically conceptualized and examined separately as motivation to learn (Colquitt et al., 2000) and motivation to transfer (Machin \& Fogarty, 1997), or a combination as training motivation (Carlson, Bozeman, Kacmar, Wright, \& McMahan, 2000). This study found the sequence of motivation to learn and motivation to transfer proved by their full mediation roles to training transfer which contributed to recognize the individual role and sequence of motivation to learn (intrinsic motivation) and motivation to transfer (extrinsic motivation) in purely trainee characteristics setting.

\subsection{Implications for practice}

In accordance with the research results, this study contributes the important role of motivation in purely trainee characteristics setting since self-efficacy in training was not found its significant association to training transfer without mediation effectiveness of motivation. Besides, the study results revealed the sequent relationship of self-efficacy, motivation to learn, motivation to transfer, and training transfer in turn with purely trainee characteristics setting. Although self-efficacy as one of the main determinants of proximal training outcomes (Haccoun \& Saks, 1998) which consist of an individual's belief that they can successfully perform a task (Wood \& Bandura, 1989), without motivation, training 
transfer will not be happened appropriately even though the individual has higher level of self-efficacy in training context. To enhance the motivation, it is necessary for organizations to build up the mechanism of fostering and encouraging employees' self-efficacy to drive one's intrinsic motivation (motivation to learn), and lift up one's extrinsic motivation (motivation to transfer) in training implementation by focusing on the intangible intrinsic rewards (Porter \& Lawler, 1968), tangible extrinsic rewards which satisfies trainees' equity feeling (Noe, 1986), and definite goal setting (Wexley \& Nemeroff, 1975).

\section{Conclusions and Recommendations}

In accordance with the purpose of this study, the findings partially confirmed the prediction role of motivation on self-efficacy to training transfer since motivation to learn and motivation to transfer fully mediate self-efficacy in turn to training transfer. Without motivation, self-efficacy hardly influences training transfer itself. In trainee's characteristics context without other variables such as training design and work environment, self-efficacy, motivation to learn, motivation to transfer, and training transfer are sorted sequentially. In conclusion, this study contributed to provide the important perception of the importance of motivation in training implementation in both theoretical and practical implications.

As to the study findings, few limitations of this study should be taken into consideration. First, training transfer was rated by self-report rather than actual observation from trainee which may limit this study. Although previous researches have utilized self-report in rating training transfer (Chiaburu \& Tekleab, 2005), which provide the evidence that trainees can accurately self-report their level of training transfer, future research may examine the level of training transfer from both trainees and their supervisor. The other, this study collected the data from participant without particular training implements which may affect the rating of motivation in this study. Future studies may be intervened some factors in study setting which may contribute to motivation.

\section{Reference}

Adams, J. S. (1963). Toward an understanding of inequity. Journal of Abnormal and Social Psychology, 67(5), 422-463. http://dx.doi.org/10.1037/h0040968

Amabile, T. M. (1993). Motivational synergy: Toward new conceptualizations of intrinsic and extrinsic motivation in the workplace. Human Resource Management Review, 3, 185-201. http://dx.doi.org/10.1016/1053-4822(93)90012-S

Arthur, W., Bennett, W., Edens, P. S., \& Bell, S. T. (2003). Effectiveness of training in organizations: A meta-analysis of design and evaluation features. Journal of Applied Psychology, 88(2), 234-245. http://dx.doi.org/10.1037/0021-9010.88.2.234

Axtell, C. M., Maitlis, S., \& Yearta, S. K. (1997). Predicting immediate and longer term transfer of training. Personnel Review, 26(3), 201-213. http://dx.doi.org/10.1108/00483489710161413

Baldwin, T. T., \& Ford, J. K. (1988). Transfer of training: A review and directions for future research.

Personnel

Psychology,

$41(1)$,

63-105. 
http://dx.doi.org/10.1111/j.1744-6570.1988.tb00632.x

2014, Vol. 4, No. 1

Baldwin, T. T., Magjuka, R. J. \& Loher, B. T. (1991). The perils of participation: Effect of choice of training on trainee motivation and learning. Personal Psychology, 44(1) 51-65. http://dx.doi.org/10.1111/j.1744-6570.1991.tb00690.x

Bagozzi, R. P., \& Yi, Y. (1988). On the evaluation of structural equation models. Journal of Academy of Marketing Science, 16(1), 74-94. http://dx.doi.org/10.1007/BF02723327

Bandura, A. (1986). Social Foundations of Thought and Action: A Social Cognitive Theory. Englewood Cliffs, NJ: Prentice Hall.

Berry, M. L., \& Morris, M. L. (2005). Organizational factors impacting sexual harassment prevention programs. In M. L. Morris \& F. Nafuko (Eds.), Proceedings of the 2005 Academy of Human Resource Development Annual Conference (pp. 1271-1278). Estes Park, CO: Academy of HRD.

Blanchard, P. N., \& Thacker, J. W. (1999). Effective Training: System, Strategies, and Practice. MA: Upper Saddle River.

Broad, M. L. (1997). Transfer concepts and research overview. In M. L. Broad (Eds,), Transfer Learning to the workplace (pp.1-18). Alexandria, VA: American Society for Training and Development.

Browne, M. W., \& Cudeck, R. (1993). Alternative ways of assessing model fit. In K. A. Bollen \& J. S. Long (Eds.), Testing structural equation models (pp. 136-162). Newbury Park, CA: Sage.

Cannon-Bowers, J. A., Salas, E., Tannenbaum, S. I., \& Mathieu, J. E. (1995). Toward theoretically based principles of training effectiveness: A model and initial empirical investigation. Military Psychology, $\quad 7, \quad$ 141-164. http://dx.doi.org/10.1207/s15327876mp0703_1

Carlson, D. S., Bozeman, D. P., Kacmar, M. K., Wright, P. M., \& McMahan, G. C. (2000). Training motivation in organizations: An analysis of individual-level antecedents. Journal of Managerial Issues, 12(3), 271-287.

Cheng, W. L., \& Ho, C. K. (2001). A review of transfer of training studies in the past decade. Personnel Review, 30(1), 102-118. http://dx.doi.org/10.1108/00483480110380163

Chiaburu, D. S., \& Lindsay, D. R. (2008). Can do or will do? The importance of self-efficacy and instrumentality for training transfer. Human Resource Development International, 11(2), 199-206. http://dx.doi.org/10.1080/13678860801933004

Chiaburu, D. S., \& Tekleab, A. G. (2005). Individual and contextual influences on multiple dimensions of training effectiveness. Journal of European Industrial Training, 29(8), 604-626. http://dx.doi.org/10.1108/03090590510627085

Colquitt, J. A., LePine, J. A., \& Noe, R. A. (2000). Toward an integrative theory of training motivation: Ameta-analytic path analysis of 20 years of research. Journal of Applied 
Psychology, 85(5), 678-707. http://dx.doi.org/10.1037/0021-9010.85.5.678

2014, Vol. 4, No. 1

Deci, E. L., \& Ryan, R. M. (2000). Self-determination theory and the facilitation of intrinsic motivation, social development, and well being. American Psychologist, 55, 68-78. http://dx.doi.org/10.1037/0003-066X.55.1.68

Ford, J., Quinones, M., Sego, D., \& Sorra, J. (1992). Factors affecting the opportunity to perform trained tasks on the job. Personnel Psychology, 45(3), 511-527. http://dx.doi.org/10.1111/j.1744-6570.1992.tb00858.x

Ford, J. K., \& Weissbein, D. A. (1997). Transfer of training: An updated review and analysis. Performance Improvement Quarterly, 22-41. http://dx.doi.org/10.1111/j.1937-8327.1997.tb00047.x

Gagné, M., \& Deci, E. L. (2005). Self-determination theory and work motivation. Journal of Organizational Behavior, 26, 331-362. http://dx.doi.org/10.1002/job.322

Haccoun, R. R., \& Saks, A. M. (1998). Training in the 21st century: Some lessons from the last one. Canadian Psychology, 39, 33-51. http://dx.doi.org/10.1037/h0086793

Hill, T., Smith, N. D., \& Mann, M. F. (1987). Role of efficacy expectations in predicting the decision to use advanced technologies: The case of computers. Journal of Applied Psychology, 72(2), 307-313. http://dx.doi.org/10.1037/0021-9010.72.2.307

Holton, E. F. III. (1996). The flawed four level evaluation model. Human Resources Development Quarterly, 7(1), 5-21. http://dx.doi.org/10.1002/hrdq.3920070103

Joreskog, K. G., \& Sorbom, D. (1996). LISREL 8: User's reference guide. Chicago: ScientificSoftware International.

Katz, M. H. (1999). Multivariable Analysis: A Practical Guide for Clinicians. UK: Cambridge University Press.

Kontoghiorghes, C. (2001). A holistic approach towards motivation to learn in the workplace . Performance Improvement Quarterly, 45-59. http://dx.doi.org/10.1111/j.1937-8327.2001.tb00229.x

Kontoghiorghes, C. (2002). Predicting motivation to learn and motivation to transfer learning back to the job in a service organization: A new systemic model for training effectiveness. Performance Improvement $\quad$ Quarterly, 114-129. http://dx.doi.org/10.1111/j.1937-8327.2002.tb00259.x

Locke, E. A. (1968). Toward a theory of task motivation and incentives. Organizational Behavior and Human Performance, 3(2), 157-189. http://dx.doi.org/10.1016/0030-5073

Locke. E. A., Shaw, K, N., Saari, L. M., \& Latham, G. P. (1981). Goal-setting and task performance: 1969-1980. Psychological Bulletin, 90(1), 125-152. http://dx.doi.org/10.1037/0033-2909.90.1.125

Machin, M. A., \& Fogarty, G. J. (1997). The effects of self-efficacy, motivation to transfer, 
and situational constraints on transfer intentions and transfer of training. Performance Improvement Quarterly, 10(2), 98-115. http://dx.doi.org/10.1111/j.1937-8327.1997.tb00051.x

Mathieu, J. E., Martineau, J. W., \& Tannenbaum, S. I. (1993). Individual and situational influences on the development of self-efficacy: Implications for training effectiveness. Personnel Psychology, 46, 125-147. http://dx.doi.org/10.1111/j.1744-6570.1993.tb00870.x

Maurer, T. J., \& Tarulli, B. A. (1994). Investigation of perceived environment, perceived outcome, and person variables in relationship to voluntary development activity by employees. Journal of Applied Psychology, 79(1), 3-14. http://dx.doi.org/10.1037/0021-9010.79.1.3

Moorhead, G., \& Griffin, M. (1992). Organizational Behavior. Boston, MA: Houghton Mifflin.

Naquin, S. S., \& Holton, E. F. III. (2002). The effects of personality, affectivity, and work commitment on motivation to improve work through learning. Human Resource Development Quarterly, 13(4), 357-376. http://dx.doi.org/10.1002/hrdq.1038

Noe, R. A. (1986). Trainees' attributes and attitudes: Neglected influence on training effectiveness. Academy of Management Review, 11(4), 736-749.

Noe, R. A., \& Schmitt, N. (1986). The influence of trainee attitudes on training effectiveness: Test of a model. Personnel Psychology, 39(3), 497-523. http://dx.doi.org/10.1111/j.1744-6570.1986.tb00950.x

Noe, R. A., \& Wilk, S. L. (1993). Investigation of the factors that influence employees' participation in development activities. Journal of Applied Psychology, 78(2), 291-302. http://dx.doi.org/10.1037/0021-9010.78.2.291

Porter, L. W, \& Lawler, E. E. (1968). Management Attitude and Performance. Florence, KY: Dorsey Press.

Quiñones, M. A. (1995). Pretraining contest effects: Training assignment as feedback. $\begin{array}{llll}\text { Journal of } \quad \text { Applied } & \text { Psychology, } & \text { 80(2), }\end{array}$ http://dx.doi.org/10.1037/0021-9010.80.2.226

Rothwell, W. J., \& Sredl, H. J. (2000). Workplace Learning and Performance: Present and Future Roles and Competencies. USA: HRD Press Inc.

Ruona, W. E., Leimbach, M., Holton, E. F., \& Bates, R. (2002). The relationship between learner utility reactions and predicted learning transfer among trainees. International Journal of Training and Development, 6(4), 218-228. http://dx.doi.org/10.1111/1468-2419.00160

Salas, E., \& Cannon-Bowers, J. A. (2001). The science of training: a decade of progress. Annual Review of Psychology, 52, 471-499. http://dx.doi.org/10.1146/annurev.psych.52.1.471

Scaduto, A., Lindsay, D., \& Chiaburu, D. S. (2008). Leader influences on training effectiveness: Motivation and outcome expectation processes. International Journal of $\begin{array}{lll}\text { Training and } \quad \text { Development, } & \text { 12(3), }\end{array}$ 
http://dx.doi.org/10.1111/j.1468-2419.2008.00303.x

Seyler, D. L., Holton, E. F. III, Bates, R. A., Burnett, M. F., \& Carvalho, M. A. (1998). Factors affecting motivation to transfer training. International Journal of Training and Development, 2 (1), 2-16. http://dx.doi.org/10.1111/1468-2419.00031

Sharon, S. N., \& Holton, E. F. (2002). The effects of personality, affectivity, and work commitment on motivation to improve work through learning. Human Resource Development Quarterly, 13(4), 357-376. http://dx.doi.org/10.1002/hrdq.1038

Stajkovic, A. D., \& Luthans, F. (1998). Self-efficacy and work-related performance: A $\begin{array}{llll}\text { meta-analysis. } & \text { Psychological } & \text { Bulletin, } & \text { 124, }\end{array}$ http://dx.doi.org/10.1037/0033-2909.124.2.240

Tai, W. T. (2006). Effects of training framing, general self-efficacy and training motivation on trainees' training effectiveness. Personnel Review, 35(1), 51-65. http://dx.doi.org/10.1108/00483480610636786

Tannenbaum, S. I., Mathieu, J. E., Salas, E., \& Cannon-Bowers, J. A. (1991). Meeting trainees' expectations: The influence of training fulfillment on the development of commitment, selfefficacy and motivation. Journal of Applied Psychology, 76(6), 759-769. http://dx.doi.org/10.1037/0021-9010.76.6.759

Tannenbaum, S. I., \& Yukl, G. (1992). Training and development in work organizations. Annual Review of Psychology, 39, 399-441. http://dx.doi.org/10.1146/annurev.ps.43.020192.002151

Tracey, J. B., Hinkin, T. R., Tannenbaum, S., \& Mathieu, J. E. (2001). The influence of individual characteristics and the work environment on varying levels of training outcomes. Human Resource Development Quarterly, 12(1), 5-23. http://dx.doi.org/10.1002/1532-1096(200101/02)12:1<5::AID-HRDQ2>3.0.CO;2-J

Velada, R., \& Caetano, A. (2007). Training transfer: The mediating role of perception of learning. Journal of European Industrial Training, 31(4), 283-296. http://dx.doi.org/10.1108/03090590710746441

Vroom, V. H. (1964). Work and Motivation. New York: Wiley.

Wexley, K. N., \& Nemeroff, W. (1975). Effectiveness of positive reinforcement and goal setting as methods of management development. Journal of Applied Psychology, 60(4), 446-450. http://dx.doi.org/10.1037/h0076912

Wood, R. E., \& Bandura, A. (1989). Social-cognitive theory of organizational management. Academy of Management Review, 14(3), 361-384.

Xiao, J. (1996). The relationship between organizational factors and the transfer of training in the electronics industry in shenzhen, China. Human Resource Development Quarterly, 7(1), 55-86. http://dx.doi.org/10.1002/hrdq.3920070107

Yamnill, S., \& McClean, G. N. (2001). Theories supporting transfer of training. Human 
Resource Development Quarterly, 12(2), 195-208. http://dx.doi.org/10.1002/hrdq.7 